International Journal of Instruction

e-ISSN: 1308-1470 • www.e-iji.net

Article submission code:

20200211112757

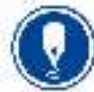

Received: $11 / 02 / 2020$

Revision: 02/09/2020
April $2021 \bullet$ Vol.14, No.2

p-ISSN: 1694-609X

pp. $155-178$

Accepted: 25/09/2020

OnlineFirst: 16/01/2021

\title{
Oral Communication Apprehension among Japanese EFL International Students in a Language Immersion Program in Malaysia
}

\section{Christine Mary Jalleh}

Corresponding author, School of Languages, Literacies \& Translation, Universiti Sains Malaysia, Malaysia, christine@usm.my

Omer Hassan Ali Mahfoodh

Dr., School of Languages, Literacies \& Translation, Universiti Sains Malaysia, Malaysia,omer@usm.my

\section{Manjet Kaur Mehar Singh}

Assoc. Prof., School of Languages, Literacies \& Translation, Universiti Sains Malaysia, Malaysia,manjeet@usm.my

Japanese EFL international students may experience high levels of apprehension when communicating in English due to their culture, educational background, attitudes towards the role of English in their society, and lack of opportunities to practice speaking in English. Although the students in this study had studied English before joining the English immersion program, their language learning experiences might not have focused on oral communication skills. EFL learners' oral communication apprehension has been examined in various contexts, but the Japanese EFL context has not received adequate attention, especially Japanese EFL international students in Malaysian institutions of tertiary education. Thus, this study examined the levels of oral communication apprehension among Japanese EFL international students in four communication contexts (group discussions, meetings, conversations, and public speaking). The study adopted a quantitative approach, using the Personal Report of Communication Apprehension (PRCA-24) to measure oral communication apprehension levels among 23 firstyear Japanese EFL students in an immersion program in a Malaysian public university. Data were analyzed using SPSS and Microsoft Excel. The results of this study revealed that most of the Japanese EFL international students exhibited a high level of oral communication apprehension. The study also revealed that the highest levels of apprehension were found in two communication contexts: group discussions and conversation, possibly because oral communication takes place spontaneously in these two communication contexts.

Keywords: oral communication apprehension, Japanese EFL students, Malaysian Public University, prca-24

Citation: Jalleh, C. M., Mahfoodh, O. H. A., \& Singh, M. K. M. (2021). Oral Communication Apprehension among Japanese EFL International Students in a Language Immersion Program in Malaysia. International Journal of Instruction, 14(2), 155-178. https://doi.org/10.29333/iji.2021.14210a 


\section{INTRODUCTION}

In foreign language teaching, the development of communication skills is one of the primary concerns (Demir, Mutlu, \& Sisman, 2018). Oral communication skills are important in various contexts including tertiary education, postgraduate education, workplace, and business (Crosling \& Ward, 2002; Moslehifar \& Ibrahim, 2012). In fact, the command of oral communication skills is essential for the development of literacy, thinking, and learning (Radzuan \& Kaur, 2010; Turiman, Omar, Daud, \& Osman, 2012). Scholars have argued that undergraduate policy and curriculum should address and encompass elements on the development of oral communication skills because undergraduate students' academic progress and future life upon graduation can be determined by the level of their abilities to express themselves efficiently and successfully (Crosling \& Ward, 2000). Additionally, undergraduate students' success in their studies depends on their command of oral communication skills (Crosling \& Ward, 2000; Kim, 2006). However, the development of oral communication skills should not be perceived as an easy task because learners intending to develop their oral communication skills encounter various difficulties and challenges (Abu Alyan, 2013; Yanagi \& Baker, 2016). Previous research focused on discovering factors that affect the development of oral communication (Huang, 2010). One of the variables that has been identified to greatly influence the development of oral communication skills is apprehension.

Research in the field of human communication has shown that one of the most frequently examined variables is communication comprehension (Levine \& McCroskey, 1990; Hasni, Ismail, \& Abdullah, 2019). Specifically, previous research has revealed that communication apprehension, or fear of communicating, is one the major factors that constrain learners from developing their communication skills effectively (Byrne, Flood, \& Shanahan, 2012). According to McCroskey (1977a), communication apprehension refers to the fear or anxiety arising from interacting with others in any context that can be real or imaginary. This concept does not only reflect the state of being anxious while speaking or having audience anxiety. Rather, it refers to a wide range of aspects that are understood and recognized as traits, contexts, and situations (Hsiao, 2010). When oral production and communication apprehension are the concerns in language learning, we get the term 'oral communication apprehension'. Although various authors have offered some definitions of oral communication apprehension, one of the earliest definitions was proposed by McCroskey (1977a) who pointed out that this term refers to "a broad-based apprehension about oral communication, from talking to a single peer to giving a speech on television” (p. 29). According to McCroskey (1984), oral communication apprehension refers to the fear or anxiety associated with situations in which oral communication is required. This has been considered an important conceptualization of oral communication apprehension (Jung \& McCroskey, 2004) and has been adopted by several researchers.

With regards to Japanese EFL students, oral communication apprehension and anxiety have been examined in some studies. Overall, most of the studies on oral communication apprehension among Japanese EFL students have reported important 
findings (refer to studies reviewed in the next section) and the participants in most of these studies were Japanese EFL students studying in Japan (Klopf \& Cambra, 1979; Yamashiro \& McLaughlin, 2001; Andrade \& Williams, 2009). In other words, oral communication apprehension among Japanese EFL students studying abroad has not been fully considered in previous studies. Furthermore, previous studies have not focused on oral communication apprehension among Japanese university students studying English in Malaysia.

In Japan, English is a classroom subject where students score well in examinations by carefully studying learning materials. In such a context, high levels of apprehension among Japanese EFL have been reported in previous studies. Kitano (2001) examined the sources of foreign language speaking anxiety among 212 students enrolled in Japanese language courses at two major state universities in USA and found a correlation between anxiety and fear of negative evaluation. Kondo and Yang (2003) found in their study of 148 university students in Japan that classroom anxiety was associated with three main factors: fear of negative evaluation by classmates, low proficiency, and speaking activities. Burden (2004) examined the degree of anxiety among 289 Japanese learning English in Okayama Shoka University, Japan and reported that half of the participants showed some level of anxiety. These results are similar to the studies by Klopf and Cambra (1979), McCroskey et al. (1985) and Pribyl et al. (1998) who found that Japanese EFL students reported high levels of communication apprehension. This can be attributed to various factors such as sociocultural variables, students' educational background, and students' lack of opportunities to communicate orally in English.

The students who participated in the current study had studied English before joining the English immersion program, however their previous educational background reflects that they have not received sufficient instruction and practice in English oral communication skills. This is evident in research studies in the Japanese context. For example, Mitchell (2017) showed that English language instruction in Japanese high schools has been highly dominated by a more passive exam-based grammar focused approach where inadequate attention is given to communicative-based approach. However, MacWhinnie and Mitchell (2017) pointed out the Ministry of Education, Culture, Sports, Science, and Technology in Japan has initiated an educational reform to develop upper secondary school students' ability to develop English speaking and communication skills. Commenting on this reform, Mitchell (2017) argued that Japanese students learning English in high school encounter various challenges because they need to study grammar, develop test taking strategies, and focus on developing communication skills.

With regards to the Japanese EFL context, most of the studies on oral communication apprehension among Japanese EFL students were participants studying in Japan (Andrade \& Williams, 2009; Klopf \& Cambra, 1979; Yamashiro \& McLaughlin, 2001). In other words, few studies have focused on communication apprehension among Japanese EFL students who are studying abroad. These studies have shown contradictory findings. For example, Tajima (2002), Matsuda and Gobel (2003), and 
Tani-Fukuchi and Sakamoto (2005) reported that Japanese EFL students who studied abroad grew in confidence in their English-speaking skills. However, Yanagi and Baker (2016) revealed that Japanese students in Australian universities encounter difficulty with speaking than with listening and pronunciation. Hence, oral communication apprehension among Japanese EFL students studying abroad, particularly in language immersion programs in an Asian country such as Malaysia, has not been fully considered in previous studies.

Thus, the purpose of this study is to examine Japanese EFL international students' level of oral communication apprehension and to assess their feelings about communicating in four communication contexts: group discussions, meetings, conversations, and public speaking. According to McCroskey and Richmond (1980), these four communication contexts are the most relevant to communication apprehension and they are representative of common communication situations. Specifically, the current study addressed the following two research questions:

1. What are the levels of Japanese EFL international students' oral communication apprehension?

2. Which oral communication contexts (group discussions, meetings, conversations, and public speaking) do Japanese EFL international students exhibit apprehension in?

The findings of the current study are significant to the fields of oral communication apprehension and English language teaching in EFL contexts. First, the findings can be useful for English language instructors of immersion programs in Malaysia and overseas because the study can, hopefully, uncover oral communication apprehension levels among Japanese EFL international students. Consequently, the results of the study can reveal important data on Japanese EFL international students' abilities, confidence, frustration and fear when they express themselves in English in formal and informal environments during the immersion program. Second, awareness of students' oral communication apprehension levels can help English language education planning units in Japan in the development of curriculum and materials to build students' selfconfidence and speaking skills in English in different communication contexts.

\section{REVIEW OF LITERATURE}

This section encompasses three sub-sections. The first sub-section offers an explanation of the four oral communication contexts that have been examined in the current study. This explanation is done here to guide the analysis of the research problem. The second sub-section presents the causes of communication apprehension based on what has been reported in previous studies. The third section presents an overview of the studies that have examined communication apprehension among Japanese EFL students.

\section{Four Oral Communication Contexts}

McCroskey (1984) proposed a taxonomy of four communication contexts that can trigger apprehension. These four communication contexts are group discussions, meetings, conversations, and public speaking. In group discussion, the participants use language to communicate orally or discuss some issues (McCroskey, Richmond, \& Davis, 1986). Participants in this communication context may vary in their 
communication skills and knowledge about the topic of discussion. Even if the size of a small group may differ from one context to another, 3-15 participants can participate in a group discussion (Myers \& Anderson, 2008; Socha, 1997). Effective participation in group discussions can provide members with a better understanding and retention of the concepts and issues that are discussed by members of the group (Young \& Henquinet, 2000). Further, group discussion is a good context for creativity where group members engage in idea generation (Sunwolf, 2002). For L2 learners, group discussions can help them improve their communication skills and build self-confidence (Bakar \& Latif, 2010).

A meeting is an oral communication context in which participants get together and discuss a problem, issue, or a special matter (Harris \& Sherblom, 2018). It has been argued that meetings are effective and important tools in oral communication (Crosling \& Ward, 2002). For L2 learners, activities that are similar to the meeting context can enable them to be engaged in face-to-face contact with other students and practice oral communication skills (Sabri \& Qin, 2014; Somsai \& Intaraprasert, 2011). Among communication contexts, a conversation is one of the most basic and essential one because it helps the participants to share thoughts, opinions, and ideas, and receive them in turn. As the participants talk without prior preparation in conversations, L2 learners may encounter various difficulties and experience high apprehension in this communication context which involves face-to-face spontaneous speaking (Somsai \& Intaraprasert, 2011). Thus, L2 learners may require major scaffolding to use these skills effectively and to construct meaning based on their understanding of other participants in the conversation (Zwiers \& Crawford, 2009). The fourth communication context in McCroskey's (1984) taxonomy is public speaking, which refers to the oral communication practice in which a speaker shares his/her ideas with an audience (Hostetler \& Kahl, 2017). In L2 contexts, learners should be trained on how to carry out public speaking effectively so that they are motivated to develop oral communication skills (Yee \& Abidin, 2014).

All these four communication contexts (group discussion, meetings, conversations, and public speaking) can be stressful for learners of English language in any context. Due to the importance of these four communication contexts, various researchers in L2 contexts have measured students' apprehension in these contexts and reported significant findings (e.g., Kitano, 2001; Yanagi \& Baker, 2016).

\section{Causes of Communication Apprehension}

Previous studies that have examined issues related to oral comprehension apprehension in the Japanese EFL context are also reviewed here. Even though McCroskey (1977b) suggested that it is difficult to get a complete list of sources of communication apprehension, there are some attempts to classify causes of communication apprehension. While some researchers preferred to offer classifications of these causes, other researchers have just listed the causes of communication apprehension. For example, McCroskey (1980) identified seven causes of communication apprehension: low intellectual skills, speech skill deficiencies, voluntary social introversion, social alienation, communication anxiety, low social self-esteem, and ethnic/cultural 
divergence in communication norms. McCroskey (1980) connected these factors to children in schools, but these factors can also be the causes of communication apprehension among adult L2 learners. Rojo-Laurilla (2005) believed that causes of communication apprehension can be grouped into two groups: internal factors (such as physiological factors) and external factors (such as the nature of the topic of discussion). Prusank (1987) offered four plausible explanations of the causes of communication apprehension: genetic predispositions, reinforcement, modelling, and learned helplessness. Recent researchers, such as Rimkeeratikul (2016), support the claim that communication apprehension can be explained through genetic and environmental factors. Molnar and Crnjak (2018) explained that while the genetic predisposition refers to the inherited characteristics that may be behind communication apprehension, environmental aspects (such as reinforcement, modelling, and learned helplessness) are factors that an individual has no control over. Yet, McCroskey (1977b) was against this conceptualization of genetic predisposition because he believed that communication apprehension is a learned trait. For him, apprehension is a trait that is associated with the reinforcement of the child's communication behaviors.

For McCroskey (1997), causes of communication apprehension might include: novelty, formality, subordinate status, and degree of attention from others. Further, some other researchers have proposed that factors such as demographic, cultural, and socioeconomic factors may be sources of communication apprehension (Alley-Young, 2005; Watson, Monroe, \& Atterstrom, 1989). Cultural differences have been reported to cause communication apprehension. For example, Alley-Young (2005) argued that in some cultures, people may prefer direct and verbally active communication, which can create apprehension for others. Hsu (2004) investigated factors that contributed to the differences in communication apprehension between Chinese in Taiwan and Americans. She reported that Taiwan college students reported significantly higher communication apprehension than Americans. She has also highlighted that differences in cultural orientations, personality traits, and communication apprehension components can be the sources of communication apprehension. She further showed that the value of being independent, unique, and direct in communication may be another cause of fear of communicating with people. Further, Hsu (2007) discussed that possible differences in communication between cultures can account for high levels of apprehension. Thaher (2005) listed the following categories of factors of communication apprehension within an EFL classroom: (1) psychological factors, which include emotion, self-esteem, anxiety, attitude, fear, and motivation; (2) instructional factors, which include goals, teachers, methods, texts, time, intensity, and means of evaluation; and (3) sociocultural factors, which include acculturation, social distance, second versus foreign language learning, and culturally accepted thought.

Manjet, David, and Choo (2011) highlighted international undergraduate students' problem of insufficient background knowledge and communicative experience with the English language in their native country during their experience as international students in a Malaysian public university. Class discussions, group discussions and open sharing of ideas on a voluntary basis are part of the requirements for an English course. The researchers used McCroskey's (1970) Personal Report of Communication Apprehension 
scale (PRCA-24) to identify oral communication apprehension faced by 17 international university students from China, Indonesia, Saudi Arabia and Thailand. The majority $(62.5 \%)$ in this group of international students reported high communication apprehension levels in public speaking.

To sum up, it is difficult for researchers to agree on a complete list of causes of communication apprehension because they vary based on the context, age of the users of language, learning environment, and other sociocultural factors.

\section{Oral Communication Apprehension among Japanese EFL Students}

This section reviews studies that have measured communication apprehension among Japanese EFL students in their country and abroad. Klopf and Cambra (1979) is one of the early studies that have examined oral communication apprehension among Japanese EFL students. They focused on learners in four countries: the US, Japan, Australia, and Korea. They hypothesized that there would be no differences in oral communication apprehension among learners in these four countries. However, their hypothesis was rejected because variations were detected among the sample taken from these four countries. Another important finding from the study is that Japanese students appeared to be shy, showing unwillingness to communicate orally, especially with those who do not belong to their in-groups.

In another study in the Japanese context, McCroskey, Gudykunst, and Nishida (1985) used PRCA-24 to examine communication apprehension among 209 Japanese students in Nihon University in Japan. The researchers wanted to compare comprehension apprehension among Japanese college students in two language contexts: speaking in English and speaking in Japanese. Although the results showed that Japanese students had a high level of communication apprehension in terms of speaking, the difference for these students speaking in English and in Japanese were not significant. In other words, there was no difference in the levels of oral communication apprehension, whether it is in English or Japanese. Pribyl, Keaten, Sakamoto, and Koshikawa (1998) also used the PRCA-24 to collect data regarding oral communication apprehension from a sample drawn from a major private university in Tokyo. They reported that the means for the PRCA-24 and its sub-dimensions for the Japanese college students were higher. McCroskey et al. (1985) found that Japanese students experienced high communication apprehension when they communicated in Japanese and their second language (L2), English. Yanagi and Baker (2016) used questionnaires and interviews to collect data from 33 undergraduate and postgraduate Japanese students. They reported that the Japanese students in Australian universities had greater difficulty with speaking than with listening and pronunciation.

Some studies have focused on anxiety and its relation to some variables such as proficiency and motivation. Kitano (2001) examined the sources of foreign language speaking anxiety among 212 students enrolled in Japanese language courses at two major state universities in USA. The researcher reported a correlation between anxiety and fear of negative evaluation. The study also revealed a correlation between anxiety and perception of low ability in relation to peers and native speakers. Thus, the study highlighted the importance of giving positive reinforcement to students who have fear of 
negative evaluation. Furthermore, the study also recommended interventions by teachers through the design of the classroom environment and the incorporation of pair and group work to create a classroom community where students can be engaged in various oral communication activities. Focusing on the anxiety of 220 Japanese junior college and university students, Yamashiro and McLaughlin (2001) reported that higher levels of anxiety tend to indicate lower levels of proficiency. Their findings also showed that a higher level of motivation may lead to a higher level of anxiety, which in turn may lead to a lower level of proficiency. Kondo and Yang (2003) found in their study of 148 university students in Japan that classroom anxiety was associated with three main factors: fear of negative evaluation by classmates, low proficiency, and speaking activities. Burden (2004) examined the degree of anxiety among 289 Japanese learning English in Okayama Shoka University, Japan. He collected data using the Foreign Language Classroom Anxiety Scale (FLCAS) which was proposed by Horwitz, Horwitz, and Cope (1986). Burden reported that half of the participants revealed some level of anxiety. He suggested that teachers should use communicative strategies that help students to minimize their level of anxiety.

Matsuda and Gobel (2004) focused on Japanese EFL students enrolled in study abroad programs. They investigated the effects of overseas experience on anxiety among Japanese college students majoring in English. They collected data using some instruments including the FLCAS (Horwitz et al., 1986) and reported that the students' overseas experience, which ranged from two weeks to five years, had a significant effect on their responses to the FLCAS. However, there was no correlation between the length of stay in a foreign country and the students' responses to the items of the FLCAS.

Two studies used a qualitative approach to obtain information on factors that cause apprehension. Williams and Andrade (2008) identified the situations that provoked anxiety among Japanese university students in EFL classes by asking 243 students to write and categorize anxiety-provoking situations they had encountered into three stages of the language-learning process: input, output, and processing. Output and processing stages made up $75 \%$ of all the anxiety-provoking situations. Half of the students perceived teachers as the source of those anxiety-provoking situations, suggesting the need for considering the improvement of student-teacher relationship. Whilst most students felt frustrated and helpless, the students who were more confident of their English abilities indicated a greater sense of resilience. Based on these findings, the researchers suggested that teachers should be aware of anxiety-provoking situations, take steps to minimize their negative effect, and provide explicit instruction on how to cope with these situations. Further research is also called on the actual effectiveness of these instructional techniques in diverse classroom settings. Matsuoka (2008) interviewed 10 Japanese students and one from Vietnam to examine factors that create communication apprehension. He reported that these factors are competitiveness, perfectionism, face-protecting orientation, and valuing reticence. However, the study did not explain how the eleven participants conceptualized factors generating apprehension. Furthermore, the findings of the study cannot be generalized due to the dependence on qualitative data obtained from a small sample size. 
Recently, MacWhinnie and Mitchell (2017) investigated L2 motivational self-system and anxiety exhibited by Japanese undergraduate students towards English language learning. They wanted to know how this correlation can mediate Japanese EFL students' ability to acquire English language skills. They collected data using a questionnaire that encompassed items on motivation, anxiety, intended effort, and English language proficiency items. They reported that the ideal L2 self and L2 learning experiences are correlated with lower anxiety levels and that this correlation, in turn resulted in positive learning results. They also revealed that while the ought-to self was found to be indicative of increased anxiety, the ought-to self was reported to be a strong indicator of motivation overall.

The review of related studies has shown that oral communication apprehension among Japanese students studying abroad has not been fully explored. Although Matsuda and Gobel (2004) focused on Japanese EFL students' overseas experience and anxiety, they did not use the PRCA-24. Additionally, the review of previous studies that examined communication apprehension among Japanese EFL students has revealed gaps in research. First, apart from Matsuda and Gobel (2004) and Yanagi and Baker (2016), no study has examined oral communication apprehension among Japanese EFL international students in overseas contexts. Second, previous studies have not focused on the measurement of communication apprehension among Japanese EFL international students in an Asian university. Thus, the current study was carried out to address these two gaps. The findings of this study can give teachers of English language courses in Malaysian and other Asian higher education institutions a better understanding of how Japanese EFL international students feel towards speaking in English when studying abroad.

\section{METHOD}

This study adopts the quantitative paradigm of research, in which a survey instrument was used to collect data (Johnson \& Christensen, 2019). In this survey, data were gathered using a questionnaire. In educational research, it is very common to use questionnaires to gather data because they are effective and generally cheaper and quicker than other methods of survey (Babbie, 2013; Larini \& Barthes, 2018). Furthermore, in this study a questionnaire was chosen for data collection because it can produce comprehensive responses from the participants within a short time (Cargan, 2007). This study utilizes the PRCA-24 because it is a self-report instrument that measures communication anxiety in different dimensions, such as public speaking, talking in meetings or classes, talking in small groups, and talking in dyads (McCroskey, 1984).

\section{Participants and the Context}

The population of this study was 30 Japanese EFL international students who were enrolled in a 3-week immersion program in a public university in Malaysia. The sample of this study consists of first-year Japanese university students who were enrolled in an English for communication course. This course was chosen because the main objective of this course is to help students to improve their oral communication skills in English. Furthermore, in this course the students were given opportunities to engage in oral 
communication tasks, such as spoken dialogues with task-related vocabulary and grammar. Dialogues as models were also played to the students as a listening task.

Twenty-three (14 male and 9 female) Japanese EFL international students were selected by employing simple random sampling where all members of the population had an equal and independent chance of being included in the sample (Ary, Jacobs, Irvine, \& Walker, 2018). The students' ages ranged between 18 and 19 years old. Slightly more than $50 \%(n=13)$ of the students studied English for an average of 6 years, while the rest of the sample studied English for 10 to 16 years. The number of female students (5 out of 8 ) who had studied English for more than 10 years outnumbered the male students (5 out of 16). These students were purposively selected because they were studying courses that focused on improvement of oral communication skills in English.

Prior to their arrival in Malaysia, the students sat for the International English Language Testing Services test in Japan. 25\% of the students scored 6.0-6.5, more than 50\% scored 5.0-5.5, while 25\% scored as low as 4.5. Mapped against the Common European Framework of Reference, only $25 \%$ of the students were categorized at Band B1 or Independent Users, while 75\% of the students were at A2 and A1 levels of Basic Users.

\section{Data Collection}

In this study, data were collected using the PRCA-24, which is widely accepted as a reliable and valid instrument for measuring communication apprehension. Compared to other rival instruments that measure communication apprehension and anxiety (e.g., FLCAS, PRCA, PRCA10, and PRCA-24B), PRCA-24 has been widely used by several researchers because it is highly reliable and has a very high predictive validity (Chen, 1994). Furthermore, it permits researchers to obtain sub-scores on four communication contexts: group discussions, meetings, conversations, and public speaking (McCroskey, 1982). There are six items for each communication context. The composite score is determined by adding the scores of the 24 items. Additionally, this instrument has a strong face validity and empirical validity and has consistently produced internal reliabilities in the .91 to .96 range. The internal reliability (Cronbach Alpha) in this study was .91 .

The PRCA-24 scale measures individuals' propensity to communicate with others (McCroskey, 1982; McCroskey, Beatty, Kearney, \& Pax, 1985). The original form of PRCA-24 was developed by McCroskey (1982). It is a Likert scale comprising twentyfour statements and requires the participants to indicate whether they strongly agree (1), agree (2), are undecided (3), disagree (4), or strongly disagree (5) with each statement. A high score indicates comparatively more oral communication apprehension and a low score means less apprehension. An online version of the questionnaire was used to gather the participants demographic data and levels of communication apprehension in different communication contexts (group discussions, meetings, conversations, and public speaking).

\section{Data Analysis}

Data were analyzed using Statistical Package for the Social Sciences (SPSS, version 23) and Microsoft Excel. Students' responses to all items of the PRCA-24 were tabulated 
and entered into an SPSS file. Table 1 shows how the levels of apprehension were identified. Based on McCroskey et al. (1985), scores of apprehension levels can range from 24-120. Scores below 51 represent people who have very low communication apprehension. Scores between 51 and 80 represent people with average communication apprehension. Scores above 80 represent people who have high levels of communication apprehension. Microsoft Excel was used for summing up scores, calculating percentages, and sorting scores from the highest score to the lowest one for the overall apprehension level and for each communication context. The researchers conferred on several occasions to revise and check the analysis of the data. They ensured that the data were correctly entered into the SPSS file and that the calculation of apprehension levels was accurate.

Table 1

Levels of communication apprehension

Level of apprehension Scores

High $\quad$ Scores between 80 and 120 indicate a high level of communication apprehension

Moderate Scores between 51 and 80 indicate a moderate level of communication apprehension

Low Scores below 51 indicate a low level of communication apprehension

\section{FINDINGS}

Oral Communication Apprehension Levels of Japanese EFL International Students

This section reports the findings to the first research question (What are the levels of Japanese EFL international students' oral communication apprehension?). The results concerning oral communication apprehension of Japanese EFL international students are displayed in Table 2 where the score of apprehension for each participant is reported. The scores are reported in a descending order (from the highest score of apprehension to the lowest one). Furthermore, Table 3 shows the frequencies and percentages of the three levels of oral communication apprehension for the 23 Japanese EFL international students.

Tables 2 and 3 reveal that 14 Japanese EFL students scored a high level of apprehension (61\%), eight Japanese EFL students scored a moderate level of apprehension (35\%), and only one student had a low level of apprehension. Those who scored high levels of apprehension were 10 male students and four female students. On the other hand, those who had a moderate level of apprehension were four male students and four female students. The only student who had a low level of apprehension was a male student. Thus, the analysis of the data showed that most of the students who participated in this study had a high level of apprehension in oral communication. The results reported in this section have focused on the overall score of apprehension. The following subsection reports the levels of apprehension in each communication context (group discussions, meetings, conversations, and public speaking).

Table 2

Oral communication apprehension levels of Japanese EFL international students

\begin{tabular}{llllll}
\hline Participant & Group Discussions & Meetings & Conversations & Public Speaking & Total Scores \\
\hline M4 & 30 & 28 & 24 & 26 & 108 \\
\hline M15 & 30 & 25 & 27 & 24 & 106 \\
\hline
\end{tabular}




\begin{tabular}{llllll}
\hline Participant & Group Discussions & Meetings & Conversations & Public Speaking & Total Scores \\
\hline M13 & 30 & 22 & 22 & 20 & 94 \\
\hline F2 & 30 & 18 & 23 & 22 & 93 \\
\hline F8 & 31 & 21 & 30 & 9 & 91 \\
\hline M11 & 27 & 21 & 21 & 19 & 88 \\
\hline M12 & 28 & 22 & 22 & 16 & 88 \\
\hline M10 & 28 & 20 & 21 & 18 & 87 \\
\hline M14 & 23 & 17 & 24 & 23 & 87 \\
\hline M8 & 28 & 20 & 18 & 17 & 83 \\
\hline F7 & 28 & 18 & 23 & 13 & 82 \\
\hline M9 & 27 & 20 & 21 & 14 & 82 \\
\hline F6 & 26 & 17 & 19 & 19 & 81 \\
\hline M2 & 24 & 18 & 21 & 18 & 81 \\
\hline M3 & 26 & 15 & 23 & 11 & 75 \\
\hline F1 & 21 & 18 & 20 & 13 & 72 \\
\hline M7 & 28 & 19 & 18 & 6 & 71 \\
\hline F4 & 24 & 17 & 16 & 13 & 69 \\
\hline M1 & 26 & 12 & 13 & 18 & 68 \\
\hline M6 & 24 & 16 & 18 & 10 & 62 \\
\hline F3 & 25 & 15 & 16 & 6 & 54 \\
\hline F5 & 21 & 7 & 18 & 8 & 48 \\
\hline M5 & 22 & 6 & 10 & 10 & \\
\hline
\end{tabular}

Table 3

Frequencies and percentages of oral communication comprehension levels (23 students)

\begin{tabular}{lll}
\hline Level of apprehension & Frequency & Percentage \\
\hline High & 14 & $61 \%$ \\
\hline Moderate & 8 & $35 \%$ \\
\hline Low & 1 & $4 \%$ \\
\hline
\end{tabular}

\section{Communication Apprehension Across Four Communication Contexts}

This sub-section reports the findings to the second research question (Which oral communication contexts do EFL Japanese students exhibit apprehension in?). Scores on the four oral communication contexts (group discussions, meetings, conversations, and public speaking) can range from 6 (a low level) to 30 (a high level). Based on McCroskey (1977a), any score above 18 indicates some degree of apprehension. Before reporting the apprehension levels for each of these four communication contexts, Table 4 below provides the overall score of communication apprehension for each communication context. The highest levels of apprehension are in two communication contexts: group discussions (100\%) and conversations (83\%).

Table 4

Overall frequencies and percentages for four communication contexts

\begin{tabular}{lll}
\hline Communication context & Frequency & Percentage \\
\hline Group discussions & 23 & $100 \%$ \\
\hline Meetings & 14 & $61 \%$ \\
\hline Conversations & 19 & $83 \%$ \\
\hline Public speaking & 10 & $43 \%$ \\
\hline
\end{tabular}




\section{Communication Apprehension Levels in Group Discussions}

Table 5 below displays the comprehension levels of the 23 Japanese EFL international students in terms of group discussions. Surprisingly, all the 23 students (100\%) showed high levels of apprehension in group discussions. It is a striking result because it reveals that Japanese EFL students exhibit high apprehension of being involved in group discussions, which involves using English orally in discussion with other participants. This reveals that this communication situation (group discussions) is a source of high apprehension among Japanese EFL students. These results indicate that participation in group discussions in English creates fear among Japanese EFL students studying overseas.

Table 5

Communication apprehension in group discussions

\begin{tabular}{ll}
\hline Participant & Score of apprehension in group discussions \\
\hline F8 & 31 \\
\hline M4 & 30 \\
\hline M15 & 30 \\
\hline M13 & 30 \\
\hline F2 & 30 \\
\hline M12 & 28 \\
\hline M10 & 28 \\
\hline M8 & 28 \\
\hline F7 & 28 \\
\hline M7 & 28 \\
\hline M11 & 27 \\
\hline M9 & 27 \\
\hline F6 & 26 \\
\hline M3 & 26 \\
\hline F3 & 26 \\
\hline M2 & 25 \\
\hline F4 & 24 \\
\hline M6 & 24 \\
\hline M14 & 24 \\
\hline M5 & 23 \\
\hline F5 & 22 \\
\hline
\end{tabular}

Communication Apprehension Levels in Meetings

In the communication context of meetings, Table 6 presents the results in a descending order. As shown in Table 6, 14 out of 23 Japanese EFL students (61\%) exhibited a high level of communication apprehension in meetings. Among those who showed high level of apprehension in meetings, 10 are male students $(43 \%)$ and 4 are female students $(17 \%)$. These results reveal that most of the participants appeared to be uncomfortable when they participate in a meeting in which English is used. 
Table 6

Communication apprehension in meetings

\begin{tabular}{ll}
\hline Participant & Score of apprehension in meetings \\
\hline M4 & 28 \\
\hline M15 & 25 \\
\hline M13 & 22 \\
\hline M12 & 22 \\
\hline F8 & 21 \\
\hline M11 & 21 \\
\hline M10 & 20 \\
\hline M8 & 20 \\
\hline M9 & 20 \\
\hline M7 & 19 \\
\hline F2 & 18 \\
\hline F7 & 18 \\
\hline M2 & 18 \\
\hline F1 & 18 \\
\hline M14 & 17 \\
\hline F6 & 17 \\
\hline F & 17 \\
\hline M6 & 16 \\
\hline F3 & 15 \\
\hline M1 & 15 \\
\hline F5 & 12 \\
\hline M5 & 7 \\
\hline
\end{tabular}

Communication Apprehension Levels in Conversations

In the communication context of conversations, Table 7 displays the results in a descending order. As reflected in Table 7, 19 out of 23 Japanese EFL students (83\%) exhibited high levels of communication apprehension in conversations. Among those who showed high levels of apprehension in conversations, 13 are male students $(57 \%)$ and 6 are female students (26\%). Based on these results, it can be recognized that most of the participants appear to feel fear when they participate in conversations in English. Furthermore, these results reflect that Japanese EFL international students do not feel relaxed when they engage in English conversations with students in universities overseas.

Table 7

Communication apprehension in conversations

\begin{tabular}{ll}
\hline Participant & Score of apprehension in conversations \\
\hline F8 & 30 \\
\hline M15 & 27 \\
\hline M4 & 24 \\
\hline M14 & 24 \\
\hline F2 & 23 \\
\hline F7 & 23 \\
\hline M3 & 23 \\
\hline M13 & 22 \\
\hline
\end{tabular}




\begin{tabular}{ll}
\hline Participant & Score of apprehension in conversations \\
\hline M12 & 22 \\
\hline M11 & 21 \\
\hline M10 & 21 \\
\hline M9 & 21 \\
\hline M2 & 21 \\
\hline F1 & 20 \\
\hline F6 & 19 \\
\hline M8 & 18 \\
\hline M7 & 18 \\
\hline M6 & 18 \\
\hline F5 & 18 \\
\hline F3 & 16 \\
\hline M1 & 16 \\
\hline M5 & 13 \\
\hline
\end{tabular}

Communication Apprehension Levels in Public Speaking

For the communication context of public speaking, Table 8 shows the results in a descending order whereby the highest levels of apprehension are listed first. As reflected in Table 8, only 10 out of 23 Japanese EFL students (43\%) exhibited a high level of communication apprehension in public speaking. Among those who showed high levels of apprehension in public speaking, eight students are male students (35\%) and two are female students (9\%). These results reveal that most of the participants do not have fear when they are engaged in public speaking. Furthermore, these results can indicate that Japanese EFL students are comfortable in giving a speech in public in English when they study abroad.

Table 8

Communication apprehension in public speaking

\begin{tabular}{ll}
\hline Participant & Score of apprehension in public speaking \\
\hline M4 & 26 \\
\hline M15 & 24 \\
\hline M14 & 23 \\
\hline F2 & 22 \\
\hline M13 & 20 \\
\hline M11 & 19 \\
\hline F6 & 19 \\
\hline M10 & 18 \\
\hline M2 & 18 \\
\hline M1 & 18 \\
\hline M8 & 17 \\
\hline M12 & 16 \\
\hline M9 & 14 \\
\hline F7 & 13 \\
\hline F1 & 13 \\
\hline F4 & 13 \\
\hline M3 & 11 \\
\hline M6 & 10 \\
\hline M5 & 10 \\
\hline
\end{tabular}




\begin{tabular}{ll}
\hline Participant & Score of apprehension in public speaking \\
\hline F8 & 9 \\
\hline F5 & 8 \\
\hline M7 & 6 \\
\hline F3 & 6 \\
\hline
\end{tabular}

\section{DISCUSSION}

Based on the two research questions addressed in this study, this section discusses the results of the study. First, the levels of Japanese EFL international students' oral communication apprehension are discussed, taking into account what previous studies have reported on communication apprehension among Japanese EFL students. Second, levels of oral communication apprehension of these students are discussed in terms of apprehension in the four communication contexts: group discussion, meetings, conversations, and public speaking.

\section{Japanese EFL International Students' Oral Communication Apprehension Levels}

In this section, we discuss the findings that are related to levels of oral communication apprehension among Japanese EFL students who were in a language immersion program at a Malaysian public university. This study reported that these students exhibited high scores of oral communication apprehension. In other words, Japanese EFL students appear to have a high level of fear and anxiety during their involvement in either real or anticipated communication with other persons. The high levels of oral communication apprehension reported in this study support the findings of Manjet et al. (2011) and Kondo and Yang (2003). While Manjet et al. (2011) revealed the presence of high levels of oral communication apprehension among international students in a Malaysian public university, Kondo and Yang (2003) attributed Japanese EFL students' anxiety to fear of negative evaluation by classmates, low proficiency, and the nature of speaking activities employed in their classrooms. The results of our study have revealed that Japanese EFL students viewed themselves as significantly apprehensive in various oral communication contexts. Thus, the results of our study confirm the findings reported in most of the previous studies that examined communication apprehension among Japanese EFL students, either in Japan or when they are international students in other countries.

High levels of oral communication apprehension among Japanese EFL international students can be attributed to their cultural background, difficulties in oral communication in English, attitudes towards the role of English in their society, and educational background. The high level of apprehension among Japanese EFL students can be attributed to their educational environment where little attention is given to the use of communication skills in English. The findings of our study are consistent with the findings of related studies that have focused on oral communication skills among Japanese EFL students. For example, Takanashi (2004) noticed that "Japanese students often feel it is difficult to acquire communicative skills in English" (p. 1). The high level of apprehension among Japanese EFL students in this study may be associated with the educational background of Japanese EFL students where traditional styles of teaching English, with a teacher-centered approach, is a common pedagogical preference (Matsuura, Chiba, \& Hilderbrandt, 2001). Furthermore, some researchers have noticed 
that Japanese EFL learners' attitude towards the role of English within their society can be one of the causes of communication apprehension. Regarding this, it has been reported that Japanese EFL students may believe that there is no immediate need for English use in their society (Maftoon \& Ziafar, 2013). This, in turn, does not help students to be involved in authentic communication where spontaneity plays an important role. Cultural factors may make Japanese EFL students reluctant to communicate orally, leading to high levels of oral communication apprehension. For example, the infrequent use of open and negative expressions in interactions and students' passive responses towards the questioning technique are some of the cultural aspects among Japanese EFL students (Maftoon \& Ziafar, 2013). These factors can contribute to the high level of communication apprehension among Japanese EFL international students when they use English for oral communication.

\section{Japanese EFL International Students' Communication Apprehension Across Four Communication Contexts}

This section discusses the findings related to Japanese EFL students' communication apprehension across four communication contexts: group discussion meetings, conversations, and public speaking. In fact, this study showed that the levels of apprehension in the four communication contexts were high for Japanese EFL international students. However, the highest levels of apprehension were in two communication contexts: group discussions (100\%) and conversations (83\%). This can be attributed to the fact that oral communication in group discussions is spontaneous where the participants do not have time to prepare for this oral communication context. Thus, the study revealed that most of the students expressed that they feel uncomfortable participating in group discussions because this communication context makes them tense and nervous. These high levels of apprehension reflected Japanese EFL students' fear of speaking up in English conversations, especially when they have conversations with new acquaintances. The study also showed that Japanese EFL students have communication apprehension in meetings and public speaking. However, higher levels of apprehension were reported in group discussions and conversations. These results can be attributed to the fact that students have time to prepare for what to talk about in meetings and in public speaking.

\section{CONCLUSIONS}

The current study examined oral communication apprehension among 23 Japanese EFL international students who were in an English language immersion program in a Malaysian public university. Data were collected using the PRCA-24 instrument and analyzed using SPSS and Microsoft Excel. The study has reported significant findings related to oral communication apprehension among Japanese EFL international students studying English in an immersion program in a Malaysian public university. The findings of this study can be summarized in four main points. First, it is obvious that this high level of communication apprehension among Japanese EFL students reflect that these students have high level of fear and anxiety when they communicate in English with others outside of Japan. Second, Japanese EFL students exhibited the highest level of oral communication apprehension in group discussions. Third, the study also revealed 
that Japanese EFL international students have a high level of communication apprehension in English conversations. Fourth, Japanese EFL international students reported communication apprehension in meetings and public speaking, but the levels were lower than the levels of apprehension in group discussions and meetings.

Oral communication apprehension has been of interest to researchers and L2 educators for more than two decades. Research on this psychological construct has shown that communication apprehension can have various negative effects on learners' performance, participation, course grades, cognitive processing, and motivation. One of the major effects of apprehension is the learners' negative perception of their abilities as compared to others.

Japanese EFL international students in this current study exhibited high apprehension levels in oral communication because they might not be equipped with the necessary knowledge of language that covers lexical items, grammatical structures, and phonological units. Although the students in this study had studied English before joining the English immersion program, their previous educational background might not have focused on the communicative aspects of language. Besides, Japanese EFL students' fear of evaluation and inability to apply communication strategies can also explain the level of oral communication apprehension they reported.

\section{SUGGESTIONS FOR FUTURE RESEARCH}

Similar to other studies that have been conducted on small scales of participants, the current study has some limitations, which can be utilized as suggestions for future research. One of the limitations of this study is the sample of the study. Generally speaking, the small sample size is considered to be a challenge for researchers because they cannot provide generalizations of their findings. In this study, the small sample size limited us to use inferential statistical analysis where relationship among variables can be measured. Another limitation of this study is that it focused only on exploring oral communication apprehension in four communication contexts. A third limitation of this study is the dependence on only quantitative data. Taking these limitations into consideration, suggestions for future research are given below.

As the participants in this study were 23 Japanese EFL international students in a language immersion program in a Malaysian public university, the findings cannot be generalized to all Japanese EFL students in Malaysia. Future researchers may consider a larger sample of Japanese EFL international students in Malaysian or other Asian institutions of higher education so that the findings can support the findings of the current study. Furthermore, large sample size can help researchers to focus on more than one issue in their studies and offer good and reliable generalizations. Thus, future researchers may focus on the correlation between the overall communication apprehension and other variables. The findings of such studies can provide useful insights on Japanese EFL international students' oral communication apprehension. Some of these variables that can draw future researcher's attention are gender, selfefficacy, self-esteem, and L2 motivational self-system. 
Another limitation of this study is that it used only quantitative data to answer the two research questions. Hence, future research may consider the adoption of a mixed methods design in which both quantitative and qualitative data are collected for triangulation purposes or to use the qualitative data to support and explain the quantitative results. Thus, future research may consider the implementation of a sequential mixed-methods design in which quantitative data can be collected using PRCA-24 and analyzed. After that, the results of PRCA-24 can be used to construct interview questions that can be geared towards explaining the levels of apprehension in the four communication contexts of PRCA-24.

Finally, future studies may adopt experimental research designs that examine the effects of an intervention program that targets decreasing oral communication apprehension. After understanding the communication situations in which Japanese EFL international students exhibit high levels of apprehension when they speak in English, it is definitely important to employ instructional strategies that can help students minimize their oral communication apprehension. This can be done through quasi-experimental studies where students' oral communication apprehension can be measured at the beginning and at the end of the intervention program to test whether the intervention can help students reduce their communication apprehension. Such intervention programs may include various instructional activities that can target the improvement of communication skills in the English language.

\section{PRACTICAL IMPLICATIONS}

Based on the findings of the current study, some pedagogical implications can be suggested. As this study showed that Japanese EFL international students have high level of oral communication apprehension, teachers in English immersion programs should consider the instructional design of English classes that can help students to minimize apprehension levels. Although it is natural for anyone to undergo a state of discomfort or anxiety during a conversation with others, particularly when group discussions are involved (Hasni et al., 2019), steps must be taken to reduce communication apprehension among EFL students. Furthermore, teachers need to guide the students on how to minimize the negative effect of high levels of apprehension through direct instruction and training. For example, teachers may need to consider designing learning environments where students enjoy participating in conversations and do not have to fear being a participant in a conversation. More practice in the use of oral skills in conversations in the English language classroom can help students to be relaxed when they start a conversation with a new acquaintance. Another activity that may be used to help students minimize oral communication apprehension is teachers' use of questioning techniques to encourage students to talk in English, either in group discussions or conversations. Teachers can also create discussion and conversation topics where a variety of answers can be accepted. In such situations, the students will not have fear concerning right or wrong answers, which will encourage them to use English freely. Besides, pair work and group tasks may be effective strategies for creating a comfortable classroom environment for students to practice speaking English comfortably. 
To help Japanese EFL international students acquire context-based vocabulary, teachers can include language-based activities such as vocabulary worksheet-based tasks, reading resource materials through sequencing activities (e.g., strip texts), information gap listening exercises from dialogues, discussions, and meetings that provide exposure to the English language in daily use.

Based on the results of high apprehension levels in some communication contexts, teachers of oral communication courses can encourage students to participate in oral communication tasks, such as charades for concrete vocabulary items, student-produced role plays, problem-solving discussions, and the production of audio or video programs. Communicative language-based tasks may provide opportunities for Japanese EFL students to develop and practice listening and speaking skills for different contexts in realistic situations they may encounter as international students studying abroad.

\section{REFERENCES}

Abu Alyan, A. (2013). Oral communication problems encountering English major students: Perspectives of learners and teachers in Palestinian EFL university context. Arab World English Journal, 4(3), 226-238.

Alley-Young, G. (2005). An individual's experience: A socio-cultural critique of communication apprehension research. Online Submission, 30(1), 36-46.

Andrade, M., \& Williams, K. (2009). Foreign language learning anxiety in Japanese EFL university classes: Physical, emotional, expressive, and verbal reactions. Sophia Junior College Faculty Journal, 29(1), 1-24.

Ary, D., Jacobs, L. C., Irvine, C. K. S., \& Walker, D. (2018). Introduction to research in education. Boston, USA: Cengage Learning.

Babbie, E. R. (2013). The basics of social research. London: Cengage Learning.

Bakar, N. A., \& Latif, H. (2010). ESL Students feedback on the use of blogs for language learning. 3L: Language, Linguistics, Literature: The Southeast Asian Journal of English Language Studies, 16(1), 120-141.

Burden, P. (2004). The teacher as facilitator: Reducing anxiety in the EFL university classroom. JALT Hokkaido Journal, 8(1), 3-18.

Byrne, M., Flood, B., \& Shanahan, D. (2012). A qualitative exploration of oral communication apprehension. Accounting Education, 21(6), 565-581.

Cargan, L. (2007). Doing social research. New York, NY: Rowman \& Littlefield.

Chen, G.-M. (1994). Social desirability as a predictor of argumentativeness and communication apprehension. The Journal of Psychology, 128(4), 433-438.

Crosling, G., \& Ward, I. (2000). Transition to university: The role of oral communication in the undergraduate curriculum. Journal of Institutional Research, 9(1), 69-77.

Crosling, G., \& Ward, I. (2002). Oral communication: The workplace needs and uses of business graduate employees. English for Specific Purposes, 21(1), 41-57. 
Demir, Y., Mutlu, G., \& Sisman, Y. S. (2018). Exploring the oral communication strategies used by Turkish EFL learners: A mixed methods study. International Journal of Instruction, 11(2), 539-554.

Harris, T. E., \& Sherblom, J. C. (2018). Small group and team communication (5th Ed.). Long Grove, Illinois: Waveland Press.

Hasni, B., Ismail, F., \& Abdullah, T. (2019). Oral communication apprehension in a small group discussion. International Journal of Recent Technology and Engineering (IJRTE), 8(1C2), 481-483.

Horwitz, E. K., Horwitz, M. B., \& Cope, J. (1986). Foreign language classroom anxiety. The Modern Language Journal, 70(2), 125-132.

Hostetler, M. J., \& Kahl, M. L. (2017). Advanced public speaking: A leader's guide: Routledge.

Hsiao, T.-Y. (2010). Testing rival measurement models of the personal report of communication apprehension in two Taiwanese samples. Psychological Reports, 107(1), 127-139.

Hsu, C. F. (2004). Sources of differences in communication apprehension between Chinese in Taiwan and Americans. Communication Quarterly, 52(4), 370-389.

Hsu, C. F. (2007). A cross-cultural comparison of communication orientations between Americans and Taiwanese. Communication Quarterly, 55(3), 359-374.

Huang, C.-P. (2010). Exploring factors affecting the use of oral communication strategies. LongHua Technology University Journal, 30, 85-104.

Johnson, R. B., \& Christensen, L. (2019). Educational research: Quantitative, qualitative, and mixed approaches. Thousand Oaks, California SAGE Publications.

Jung, H. Y., \& McCroskey, J. C. (2004). Communication apprehension in a first language and self-perceived competence as predictors of communication apprehension in a second language: A study of speakers of English as a second language. Communication Quarterly, 52(2), 170-181.

Kim, S. (2006). Academic oral communication needs of East Asian international graduate students in non-science and non-engineering fields. English for Specific Purposes, 25(4), 479-489.

Kitano, K. (2001). Anxiety in the college Japanese language classroom. The Modern Language Journal, 85(4), 549-566.

Klopf, D. W., \& Cambra, R. E. (1979). Communication apprehension among college students in America, Australia, Japan, and Korea. The Journal of Psychology, 102(1), 27-31.

Kondo, S., \& Yang, Y.-L. (2003). The English language classroom anxiety scale: Test construction, reliability, and validity. JALT Journal, 25(2), 593-598.

Larini, M., \& Barthes, A. (2018). Quantitative and statistical data in education: From data collection to data processing. Hoboken, NJ: John Wiley \& Sons. 
Levine, T. R., \& McCroskey, J. C. (1990). Measuring trait communication apprehension: A test of rival measurement models of the PRCA-24. Communications Monographs, 57(1), 62-72.

MacWhinnie, S. G., \& Mitchell, C. (2017). English classroom reforms in Japan: A study of Japanese university EFL student anxiety and motivation. Asian-Pacific Journal of Second and Foreign Language Education, 2(7), 1-13

Maftoon, P., \& Ziafar, M. (2013). Effective factors in interactions within Japanese EFL classrooms. The Clearing House: A Journal of Educational Strategies, Issues and Ideas, 86(2), 74-79.

Manjet, K., David, A. R., \& Choo, J. C. S. (2011). Communication apprehension among international undergraduates: The impact on their communicative skills. Modern Journal of Language Teaching Methods, 1(2), 18-30.

Matsuda, S., \& Gobel, P. (2004). Anxiety and predictors of performance in the foreign language classroom. System, 32(1), 21-36.

Matsuoka, R. (2008). Communication apprehension among Japanese college Students. Journal of Pan-Pacific Association of Applied Linguistics, 12(2), 37-48.

Matsuura, H., Chiba, R., \& Hilderbrandt, P. (2001). Beliefs about learning and teaching communicative English in Japan. JALT Journal, 23(1), 67-82.

McCroskey, J. C. (1970). Measures of communication-bound anxiety. Speech Monographs, 37(4), 269-277.

McCroskey, J. C. (1977a). Classroom consequences of communication apprehension. Communication Education, 26(1), 27-33.

McCroskey, J. C. (1977b). Oral communication apprehension: A summary of recent theory and research. Human Communication Research, 4(1), 78-96.

McCroskey, J. C. (1980). Quiet children in the classroom: On helping not hurting. Communication Education, 29, 239-244.

McCroskey, J. C. (1982). Oral communication apprehension: A reconceptualization. Annals of the International Communication Association, 6(1), 136-170.

McCroskey, J. C. (1984). The communication apprehension perspective. In J. A. Daly \& J. C. McCroskey (Eds.), Avoiding communication: Shyness, reticence, and communication (pp. 13-38). Beverly Hills, CA: SAGE Publications

McCroskey, J. C. (1997). Willingness to communicate, communication apprehension, and self-perceived communication competence: Conceptualizations and perspectives. In J. A. Daly, J. C. McCroskey, T. H. J. Ayres, \& D. M. Ayres (Eds.), Avoiding communication: Shyness, reticence, and communication apprehension (pp. 75-108). Cresskill, NJ: Hampton Press.

McCroskey, J. C., \& Richmond, V. P. (1980). The quiet ones: Shyness and communication apprehension. Scottsdale, AZ: Gorsuch Scarisbrick. 
McCroskey, J. C., Beatty, M. J., Kearney, P., \& Pax, T. G. (1985). The content validity of the PRCA-24 as a measure of communication apprehension across communication contexts. Communication Quarterly, 33(3), 165-173.

McCroskey, J. C., Gudykunst, W. B., \& Nishida, T. (1985). Communication apprehension among Japanese students in native and second language. Communication Research Reports, 2, 11-15.

McCroskey, J. C., Richmond, V. P., \& Davis, L. M. (1986). Apprehension about communicating with supervisors: A test of a theoretical relationship between types of communication apprehension. Western Journal of Speech Communication, 50(2), 171-182.

Mitchell, C. (2017). Language education pressures in Japanese high schools. JALT Shiken, 21(1), 1-11.

Molnar, D., \& Crnjak, G. (2018). Exploring foreign language communication apprehension among the English language university students in the English language classroom setting. European Journal of Social Sciences Education and Research, 5(2), 27-39.

Moslehifar, M. A., \& Ibrahim, N. A. (2012). English language oral communication needs at the workplace: Feedback from human resource development (HRD) trainees. Procedia-Social and Behavioral Sciences, 66, 529-536.

Myers, S. A., \& Anderson, C. M. (2008). The fundamentals of small group communication: Sage Publications.

Pribyl, C. B., Keaten, J. A., Sakamoto, M., \& Koshikawa, F. (1998). Assessing the cross-cultural content validity of the Personal Report of Communication Apprehension scale (PRCA-24). Japanese Psychological Research, 40(1), 47-53.

Prusank, D. T. (1987). Communication apprehension: A summary of research in elementary schools. Journal of Thought, 38-43.

Radzuan, N. R. M., \& Kaur, S. (2010). A survey of oral communication apprehension in English among ESP learners in an engineering course. English for Specific Purposes World, 31(10), 1-14.

Rimkeeratikul, S. (2016). Communication apprehension in L2 among MA students majoring in English in Bangkok, Thailand. LEARN Journal: Language Education and Acquisition Research Network, 9(2), 14-21.

Rojo-Laurilla, M. A. (2008). English for maritime purposes: Communication apprehension and communicative competence among maritime students in the Philippines. Reflections on English Language Teaching, 6(2), 39-58.

Sabri, U., \& Qin, T. Y. (2014). Communication Apprehension among Nilai College Students. Advances in Language and Literary Studies, 5(5), 46-49.

Socha, T. J. (1997). Group communication across the life span. In L. R. Frey \& J. K. Barge (Eds.), Managing group life: Communicating in decision-making groups (pp. 328). Boston: Houghton Mifflin. 
Somsai, S., \& Intaraprasert, C. (2011). Strategies for coping with face-to-face oral communication problems employed by Thai university students majoring in English. GEMA Online: Journal of Language Studies, 11(3).

Sunwolf, A. (2002). Getting to "groupaha!": Provoking creative processes in task groups. In L. R. Frey (Ed.), New directions in group communication (pp. 203-217). Thousand Oaks, CA: Sage.

Tajima, M. (2002). Motivation, attitude, and anxieties toward learning English as a foreign language: A survey of Japanese university students in Tokyo. Gengo no Sekai, 20(1/2), 115-155.

Takanashi, Y. (2004). TEFL and communication styles in Japanese culture. Language Culture and Curriculum, 17(1), 1-14.

Tani Fukuchi, N., \& Sakamoto, R. (2005). Affective dimensions of the Japanese foreign language learner: Implications for psychological learner development in Japan. Journal of Multilingual and Multicultural Development, 26(4), 333-350.

Thaher, M. (2005). Communication apprehension among An-Najah National University students. An-Najah Univ. Journal for Research (H. Sc), 19(2), 628-678.

Turiman, P., Omar, J., Daud, A. M., \& Osman, K. (2012). Fostering the 21st century skills through scientific literacy and science process skills. Procedia-Social and Behavioral Sciences, 59, 110-116.

Watson, A. K., Monroe, E. E., \& Atterstrom, H. (1989). Comparison of communication apprehension across cultures: American and Swedish children. Communication Quarterly, 37(1), 67-76.

Williams, K., \& Andrade, M (2008). Foreign language learning anxiety in Japanese EFL university classes: Causes, coping, and locus of control. Electronic Journal of Foreign Language Teaching, 5(2), 181-191.

Yamashiro, A. D., \& McLaughlin, J. (2001). Relationships among attitudes, motivation, anxiety, and English language proficiency in Japanese college students. In P. Robinson, M. Sawyer, \& S. Ross (Eds.), Second language acquisition research in Japan: JALT Applied Materials Series (pp. 19-33). Tokyo: Japan Association of Language Teachers Press

Yanagi, M., \& Baker, A. A. (2016). Challenges experienced by Japanese students with oral communication skills in Australian universities. TESOL Journal, 7(3), 621-644.

Yee, K. M., \& Abidin, M. J. Z. (2014). The use of public speaking in motivating ESL learners to overcome speech anxiety. International Journal on Studies in English Language and Literature, 2(11), 127-135.

Young, C. B., \& Henquinet, J. A. (2000). A conceptual framework for designing group projects. Journal of Education for Business, 76(1), 56-60.

Zwiers, J., \& Crawford, M. (2009). Accelerating oral language with academic conversations. Educational Leadership, 66(7), 70. 